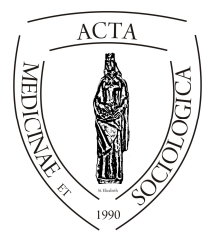

Acta Medicinae et

Sociologica (2020)

Vol. 11., Különszám. (76-87)

doi:

\title{
A külföldi munkavállalás hatása a sportolási szokásokra
}

\author{
Kosztin Nikolett $^{1}$, Balatoni Ildikó ${ }^{2}$ \\ ${ }^{1}$ ügyvivő szakértő, Debreceni Egyetem Klinikai Központ Minőségügyi Iroda, 4032 Debrecen, Nagyerdei krt.98. \\ ${ }^{2}$ operatív igazgató, Debreceni Egyetem Klinikai Központ Operatív Igazgatóság, 4032 Debrecen, Nagyerdei krt.98.
}

\begin{tabular}{ll}
\hline \multicolumn{1}{c}{ INFO } & \multicolumn{1}{c}{ ABSTRACT } \\
\hline $\begin{array}{l}\text { Dr. Balatoni Ildikó } \\
\text { balatoni@med.unideb.hu }\end{array}$ & $\begin{array}{l}\text { Abstract. Earlier research on foreign employment has } \\
\text { shown that the target country not only offers benefits, but } \\
\text { can also pose risks to people that could endanger the health } \\
\text { of the person concerned. The question in this matter arises } \\
\text { Keywords: } \\
\text { concerning the importance of being aware of the role of } \\
\text { habits, physical activity, } \\
\text { lifestyle }\end{array}$ \\
$\begin{array}{l}\text { regular exercise in the health of the people working abroad } \\
\text { and whether the frequently occurring illnesses observed } \\
\text { among them may be correlated with the possible lack of } \\
\text { regular exercise. During our research, we asked Hungarians } \\
\text { working abroad - in Germany - about their sporting habits. }\end{array}$ \\
$\begin{array}{l}\text { 60 respondents, in contrast to expectations based on data } \\
\text { from previous studies, reported higher levels of regular } \\
\text { physical activity during their stay abroad than before (in }\end{array}$ \\
$\begin{array}{l}\text { Hungary). The combined effect of a number of factors can } \\
\text { affect the concerned individuals in this respect, mostly the }\end{array}$ \\
$\begin{array}{l}\text { social and built environment. This validates the need for the } \\
\text { nation-wide development of a health-conscious lifestyle in }\end{array}$ \\
Hungary.
\end{tabular}

\section{Kulcsszavak:}

külföldi munkavállalás, sportolási szokások, fizikai aktivitás, életmód
Absztrakt: Korábbi, külföldi munkavállalást vizsgáló kutatások rámutattak arra, hogy a célország nemcsak elönyöket kínál, hanem kockázatokat is jelenthet az emberek számára, melyek veszélyeztethetik az érintett személy egészségét. Felvetődik a kérdés, hogy fontos lenne annak ismerete, hogy a külföldi munkavállalók egészségmegőrzésében milyen szerepet játszik a rendszeres testmozgás, illetve a megfigyelt, gyakran előforduló betegségek korreláltathatóak-e a rendszeres testmozgás esetleges hiányával. Kutatásunk során, külföldön - Németországban - dolgozó magyarokat kérdeztünk sportolási szokásaikról. A válaszadó 60 fö - a korábbi tanulmányok adataira alapozott várakozással szemben - magasabb arányú rendszeres fizikai aktivitásról számolt be külföldön tartózkodása alatt, mint azt megelőzően.

Ebben számos tényező együttes hatása befolyásolhatja 
az érintetteket, de leginkább a társadalmi és az épített környezet. Ez alátámasztja az egészségtudatos életmód társadalmi szintü fejlesztésének szükségességét Magyarországon.

A publikáció elkészítését az EFOP-3.6.2-16-2017-00003 számú projekt támogatta. A projekt az Európai Unió támogatásával, az Európai Szociális Alap társfinanszírozásával valósult meg.

\section{Bevezetés}

Az Európai Unióban a szabad munkaerő-áramlás lehetősége 2004 után gyors munkaerővándorlást indított el a kelet-európai országokból, amely mind a fogadó, mind a kibocsájtó országok munkaerőpiacain jelentős változásokat idézett elő. (Kahanec és munkatársai 2016). Számos külföldi és hazai kutató vizsgálta az elvándorlás kedvező és kedvezőtlen hatásait, szimulációs modelleket alkotva elemezték a migráció következtében bekövetkező alkalmazkodást (Elsner 2013; Bodnár-Szabó 2014; Dustmann és munkatársai 2015; Hazans 2016). Ugyancsak vizsgálatok tárgya volt a kivándorlók társadalmi és demográfiai összetétele, és az elköltözött családok szemszögéből is elemezték a kialakult helyzetet (Blaskó és Gödri 2016; Hárs és Simon 2016).

A 2008-as gazdasági világválság az Európai Unióban is jelentős negatív hatást gyakorolt, melynek következtében mintegy 6,7 millió állás szünt meg (Bocskor 2016). Bár az egyes országokat különböző mértékben érintette a válság, általánosan megállapítható volt, hogy elsősorban az alacsony képzettségüek és a fiatal munkavállalók iránt csökkent nagymértékben a kereslet.

A Hárs és Simon (2016) kutatásuk során úgy becsülték, hogy 2011 és 2016 között Magyarországról évente a 18-65 éves korosztály mintegy 2\%-a keresett munkát külföldön, de mintegy 50\%-uk hazajött és ismételten itthon helyezkedett el. A régiókat vizsgálva a kutatók megállapították, hogy a dél-dunántúli és az északmagyarországi területekről volt legmagasabb az elvándorlás aránya, azonban ÉszakMagyarországon az átlagnál magasabb volt a visszatérők aránya is. A végzettségeket tekintve a felsőfokú végzettségü munkavállalók kivándorlási- és hazatérési aránya az átlagostól elmaradt. Megállapították, hogy míg az iskolai végzettség jelentősen befolyásolta a külföldre vándorlást, a hazatérésre nem volt szignifikáns hatása. A foglalkozások vonatkozásában a vendéglátáshoz kapcsolódó, az építőipari, valamint a gépjármüvezető foglalkozások esetében volt jelentős növekvő tendencia. A nemek közötti megoszlást vizsgálva megállapítható volt, hogy a férfiak aránya duplája a külföldön munkát vállaló nőkhöz viszonyítva, az életkor is befolyásoló tényező a folyamatban, 40 év felett jelentősen csökken a külföldi munkavállalás esélye (Czibik és munkatársai 2014).

A magyarországi álláskeresők legnépszerübb célországai Ausztria, Németország és az Egyesült Királyság voltak (Blaskó és Fazekas 2016).

Kutatók azt is vizsgálták, hogy hogyan érinti a gyermekeket a család külföldre költözése, vagy éppen csak az egyik szülő külföldi munkavállalása következtében a szülö hiánya (Votisky 2015, 2016; Szabó 2016). A 2011-es népszámlálás adatai alapján a munkaerő-vándorlás mintegy 22 ezer kiskorút érintett Magyarországon, akik tartósan vagy ideiglenesen, de szülö/szülök nélkül éltek. 
Ugyancsak vizsgálták a kutatók a magyar fiatalok külföldi munkavállalásának motivációit, hatásait, lehetőségeit (Kulinyi 2015; Kállai és munkatársai 2016) és a nemek közötti különbségeket a nők munkaerőpiaci helyzetének és foglalkoztatottságuk változásainak tükrében (Fazekas és Köllő 2017).

A munkaerő-vándorlás nem csak az érintett országok munkaerőpiacain okozott változást, de jelentősen befolyásolta az érintett emberek társadalmi környezetét is. A migráns munkavállalók egészségügyi állapotát vizsgáló, átfogó tanulmányban (Mucci és munkatársai 2018) mintegy 68 publikáció alapján kutatók megállapították, hogy a legnagyobb kockázatot a különböző infekciók, az anyagcsere és kardiovaszkuláris betegségek jelentik, amelyek az alacsonyabb életminőség okán, különösen a helyi egészségügyi szolgáltatásokhoz való bonyolult hozzáférési lehetőség következtében lépnek fel. Az ENSZ legutolsó becslését alapul véve a világon 2000 és 2017 között a külföldön munkát keresők száma 173 millióról mintegy 258 millióra nőtt. A hazájukat figyelembe véve több mint 100 millió kivándorló volt Ázsiából (különösen Indiából), ezt követte Európa (61 millió), majd Latin-Amerika (38 millió) és Afrika (36 millió).

Más kutatások rámutattak arra is, hogy a külföldön történő munkavállalás sok esetben együtt jár a táplálkozási szokások megváltozásával (Desai és munkatársai 1980), a megszokott társadalmi- és szociális környezet elvesztésével és ennek következtében elszigetelődéssel, a családi kapcsolatok - ha átmeneti időre is - fellazulásával. Mindezek az érintett munkavállalók mentális- és fizikális állapotának romlását idézhetik elő, melyek a megbetegedések kockázatát jelentősen növelik (Tsai 2012).

Számos tanulmány igazolta, hogy az egészségmegőrzés egyik fontos összetevője a fizikai aktivitás. A rendszeres mozgás csökkenti a szív- és érrendszeri és cukorbetegség kialakulásának valószínúségét (Warburton és munkatársai 2006; Matthews és munkatársai 2000), javítja a fertőző betegségekkel szembeni ellenálló képességet és hozzájárul a mentális jólét fenntartásához (Andersen és munkatársai 2000; Bener 2017).

Fontosnak tartjuk hangsúlyozni, hogy párhuzamosság figyelhető meg a külföldi munkavállalók körében leggyakrabban előforduló - a fentiekben már idézett - megbetegedések, valamint a rendszeres testmozgás által leginkább javítható patológiás elváltozások között. Mindezek alapján fontos lenne annak ismerete, hogy a külföldi munkavállalók egészségmegőrzésében milyen szerepet játszik a rendszeres testmozgás, illetve a megfigyelt, gyakran előforduló betegségek korreláltathatóak-e a rendszeres testmozgás esetleges hiányával.

Vizsgálatunkban éppen ezért kíváncsiak voltunk arra, hogy a külföldön munkát vállaló magyarok sportolási szokásai megváltoznak-e, és ha igen, hogyan.

\section{Anyag és módszer}

Jelen kutatásunkban arra kerestük a választ, hogy azokra a magyar felnőttekre, akik élethelyzetükből adódóan nem Magyarországon élnek és dolgoznak, hogyan hat a sportolás tekintetében az idegen környezet. A kutatást kérdőíves felmérés formájában végeztük. Kíváncsiak voltunk arra, hogy változott-e az adott személy sportolási 
szokása annak következtében, hogy akár csak átmenetileg is, de külföldre költözött. Jelen vizsgálat során alapvetően a Németországban élő magyarokra fókuszáltunk. Mindösszesen 60, Németországban élő magyart kerestünk meg a kérdőívvel. Törekedtünk arra, hogy felmérésünk a Németországban dolgozók életkora és iskolai végzettsége szempontjából átfogó legyen. Ennek érdekében megkerestünk egy olyan civil csoportot, mely számos ott élő magyar munkavállalóval tart fenn rendszeres kapcsolatot és számukra közösségi programokat szervez. A felmérésünket ezen csoport tagjai körében végeztük. A kérdőív összeállításakor fontosnak tartottuk, hogy annak első részében a demográfiai adatokra is rákérdezzünk.

Az a hipotézis vezérelt minket a kutatásunk elején, hogy a megváltozott élethelyzetnek és lakhelynek valamilyen mértékben hatnia kell az adott személyre is. A kérdőív kitöltése önkéntes és anonim volt. A kitöltött kérdőívek feldolgozásra EvaSys programmal került sor.

\section{Eredmények}

A megkérdezettek nemek szerinti megoszlását tekintve megállapítható, hogy a válaszadók közel fele (47,5\%) nő, míg 52,5\% férfi. Az életkorokat tekintve látszik (1. ábra), hogy a 30-45 éves korosztály (31-35 éves 16,7\%, 36-40 éves 26,7\%, 41-45 éves 13,3\%) külföldi munkavállalása a legjellemzőbb. Meglepő volt számunkra azonban az, hogy több $(8,3 \%)$ olyan munkavállaló is volt a kitöltők között, akik betöltötték a 60 . életévüket.

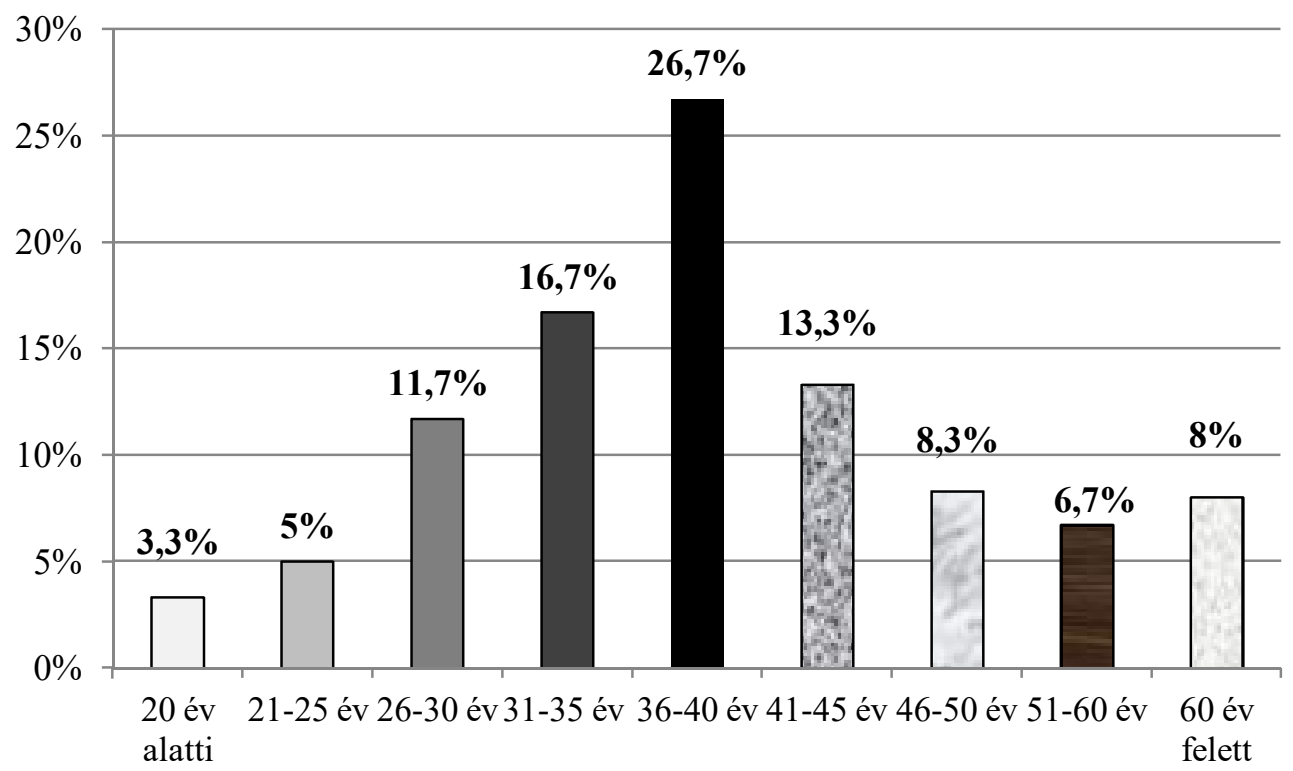

Forrás: saját szerkesztés

1. ábra. A megkérdezettek kor szerinti megoszlása 
$\mathrm{Az}$ iskolai végzettség tekintetében inkább a szakmunkás és szakiskolai (40,7\%), valamint a gimnáziumi érettségi $(35,6 \%)$ végzettséggel rendelkezők kivándorlása a megfigyelhetö, de nem ritka az egyetemi vagy föiskolai végzettséggel bírók $(23,7 \%)$ külföldi jelenléte sem.

A külföldi lakóhely választás vonatkozásában azt figyeltük meg, hogy a városokban telepedett le a válaszadó magyar munkavállalók nagy része (69\%).

A megkérdezettek családi állapotát vizsgálva számunkra is érdekes volt, hogy a legtöbben házasnak (55\%), egyedül élőnek 45,6\%-ban vallották magukat, azonban csak 24,6\%-uk él a családjával külföldön. Mindezek tükrében kijelenthető, hogy a külföldi munkavállalás és a családok szétszakadása kéz a kézben jár.

Arra a kérdésünkre, hogy külföldön milyen munkakört töltenek be, sokrétü választ kaptunk. Két munkakör emelkedett ki a többiek sorából: az egyik az ipar, építőipar 26,7\%-kal, a másik pedig a vendéglátás, 16,7\%-kal, de többen dolgoznak irodai, ügyviteli alkalmazottként $(8,3 \%)$, valamint jármúvezetőként $(6,7 \%)$ is (2. ábra).

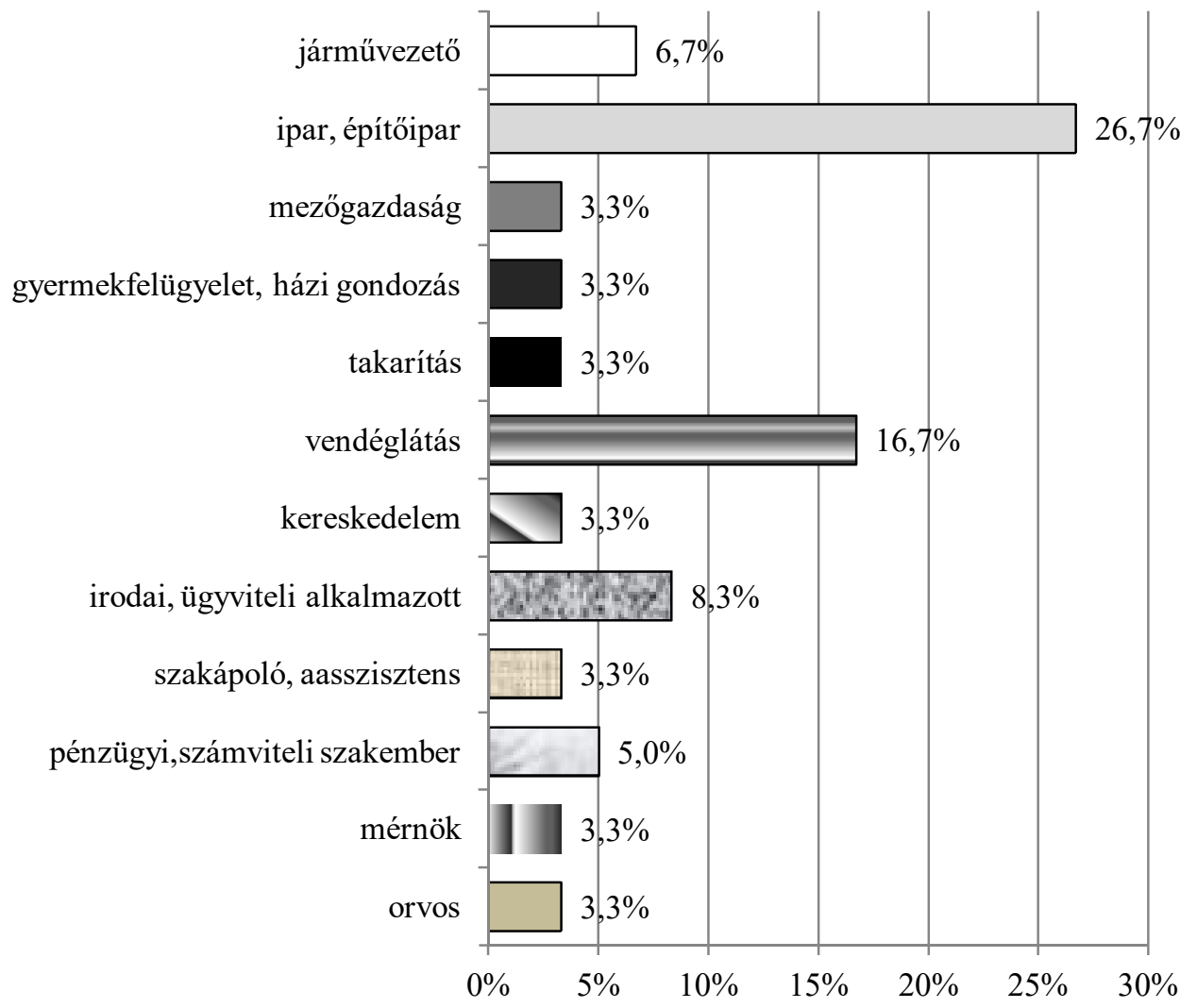

Forrás: saját szerkesztés

2. ábra. A munkavállalók által külföldön betöltött munkakörök

A válaszadók nagy része már több mint 3 éve dolgozik Németországban (3-4 éve $32,2 \%, 5-6$ éve $15,3 \%$ és több mint 6 éve $35,6 \%$ ) (3. ábra). 


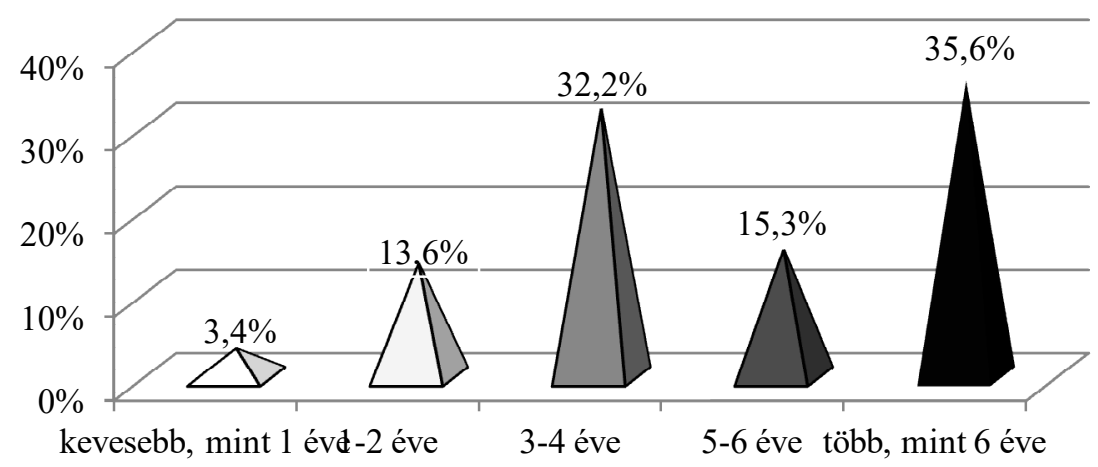

Forrás: saját szerkesztés

3. ábra. A külföldi munkavállalás időtartama

A legtöbben (69,8\%) azt állították, hogy hétköznaponként 7-8 óránál nem dolgoznak kevesebbet, míg hétvégenként 51,9\% nem dolgozik. A jelenlegi kutatásunk alapvetően arra irányult, hogy változtak-e és ha igen, miben a külföldön munkát vállaló magyarok sportolási szokásai annak hatására, hogy már nem Magyarországon dolgoznak. Erre a kérdésre azon két kérdésünk összevetésével kaptuk meg a választ, hogy a külföldre költözésüket megelőzően rendszeresen sportoltak-e (sportolás alatt itt a minimálisan 30 perc folyamatos fizikai aktivitást értettük legalább hetente 2 alkalommal.), illetve amióta külföldön élnek sportolnak-e rendszeresen. Az 6. ábra egyértelmüen bemutatja a két időszak közötti különbséget a sportolás vonatkozásában. Amíg a válaszadók Magyarországon éltek és dolgoztak, hozzávetőlegesen a megkérdezettek fele sportolt rendszeresen $(51,7 \%)$, miután külföldön vállaltak munkát a rendszeres fizikai aktivitást végzők aránya több mint háromnegyedére nőtt (76,8\%).

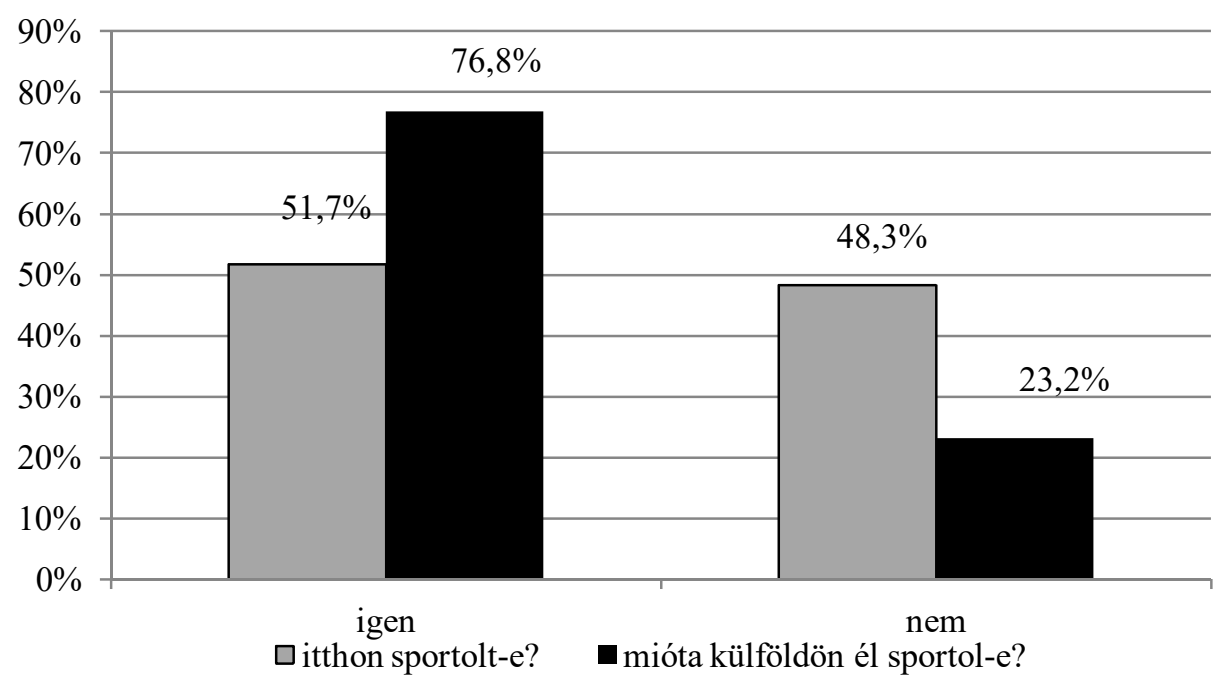

Forrás: saját szerkesztés

4. ábra. A rendszeresen sportolók és nem sportolók aránya, Magyarországon és külföldön 
Tovább vizsgálva a sportolási szokások megváltozását, egyénekre lebontva elemeztük, hogy a külföldre költözés milyen irányú változást eredményezett. Megállapítottuk, hogy többségük $(71,7 \%)$ szokásait ezen a téren a külföldi munkavállalás nem változtatta meg, 26,7\%-uk bár itthon nem sportolt, a Németországba költözést követően elkezdett sportolni, csupán egyetlen olyan válaszadó volt, aki a sportolást abbahagyta (5. ábra). Elemeztük továbbá, hogy a kint tartózkodás időtartama növeli-e annak valószínüségét, hogy valaki elkezdjen sportolni. Ehhez a válaszok alapján pontértékeket rendeltünk a sportolásban bekövetkezett változáshoz, nevezetesen, ha nem történt változás 0 , ha pozitív vagy negatív irányú változás következett be, akkor rendre +1 vagy -1 értéket adtunk. Bár a 3-4 és több mint 6 éve kint tartózkodók esetén megfigyelhető volt szignifikáns (rendre $\mathrm{p}<0,010$ és $\mathrm{p}<0,011$ ) pozitív hatás, öszszességében korrelációt a kint tartózkodás időtartama és a sportolás pozitívirányú változása között nem sikerült kimutatni $\left(r^{2}=0,0027\right)$.

$60 \%$

$50 \%$

$50,0 \%$

$40 \%$

$26,7 \%$

$21,7 \%$
$20 \%$
$10 \%$
$0 \%$

nem-nem

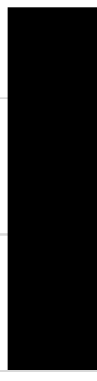

nem-igen

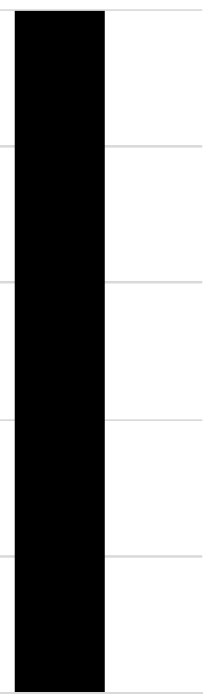

igen-igen

Forrás: saját szerkesztés

5. ábra. Sportolási szokások változásának iránya a külföldi munkavállalás hatására (nem nem sportol, igen - sportol; a szópároknál elöl a kiköltözés előtti, hátul a jelenlegi szokás)

Amikor arra kerestük a választ, hogy mit sportoltak Magyarországon illetőleg külföldön, jelentős eltéréseket találtunk. Azokra, akik a sportolást választják az alatt is, míg külföldön dolgoznak, egyértelmüen hat a külföldi lakhely adottsága. A Németországban sportoló munkavállalók 50\%-a választja a nordic walkingot, míg 36,7\% síel, 28,3\% kerékpározik, 26,7\% fut. Azok, akik Magyarországon sportoltak, a futást választották a legtöbben (a válaszadók 15\%-a). E mellett az edzőtermi edzést, valamint a tornát választók voltak még viszonylag nagyobb számban $(8,3 \%$ - 8,3\%) (6. ábra). 


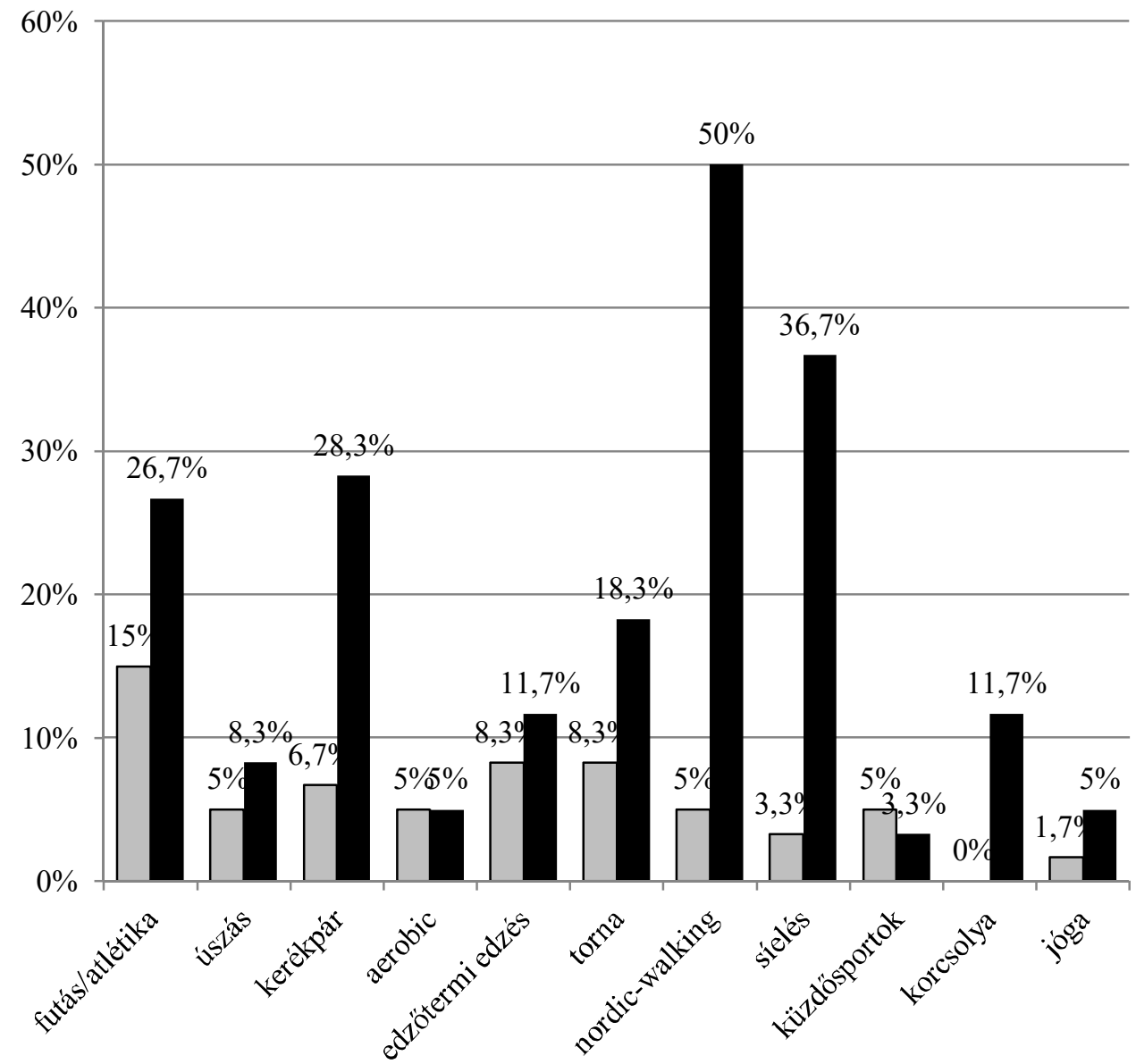

$\square$ Mit sportolt Magyarországon? - Mit sportol külföldön?

Forrás: saját szerkesztés

6. ábra. A választott sportok összehasonlítása, Magyarországon illetve külföldön (A válaszadók több választ is megjelölhettek egyidejüleg.)

A rendszeresen sportoló külföldi munkavállalók közel háromnegyede (68,3\%) nyilatkozta, hogy szabadtéren sportol és csak kicsivel több, mint a harmaduk (35\%) teszi ugyanezt valamilyen sportklubban, 23,3\% pedig otthon.

A külföldön fizikai aktivitást végzők motivációját vizsgálva (többszörös választás lehetőségével) azt az eredményt kaptuk (7. ábra), hogy a válaszadók közel háromnegyede azért sportol, hogy jól érezze magát a bőrében $(74,4 \%)$, a fele a barátaival együtt sportol (51,2\%), szintén közel a fele (48,8\%) azért sportol, hogy javítsa illetve fenntartsa az erőnlétét és egészségesebben éljen, míg több, mint az egyharmaduk szerint Németországban több lehetőségük adódik arra, hogy fizikai aktivitást végezzenek $(37,2 \%)$. 


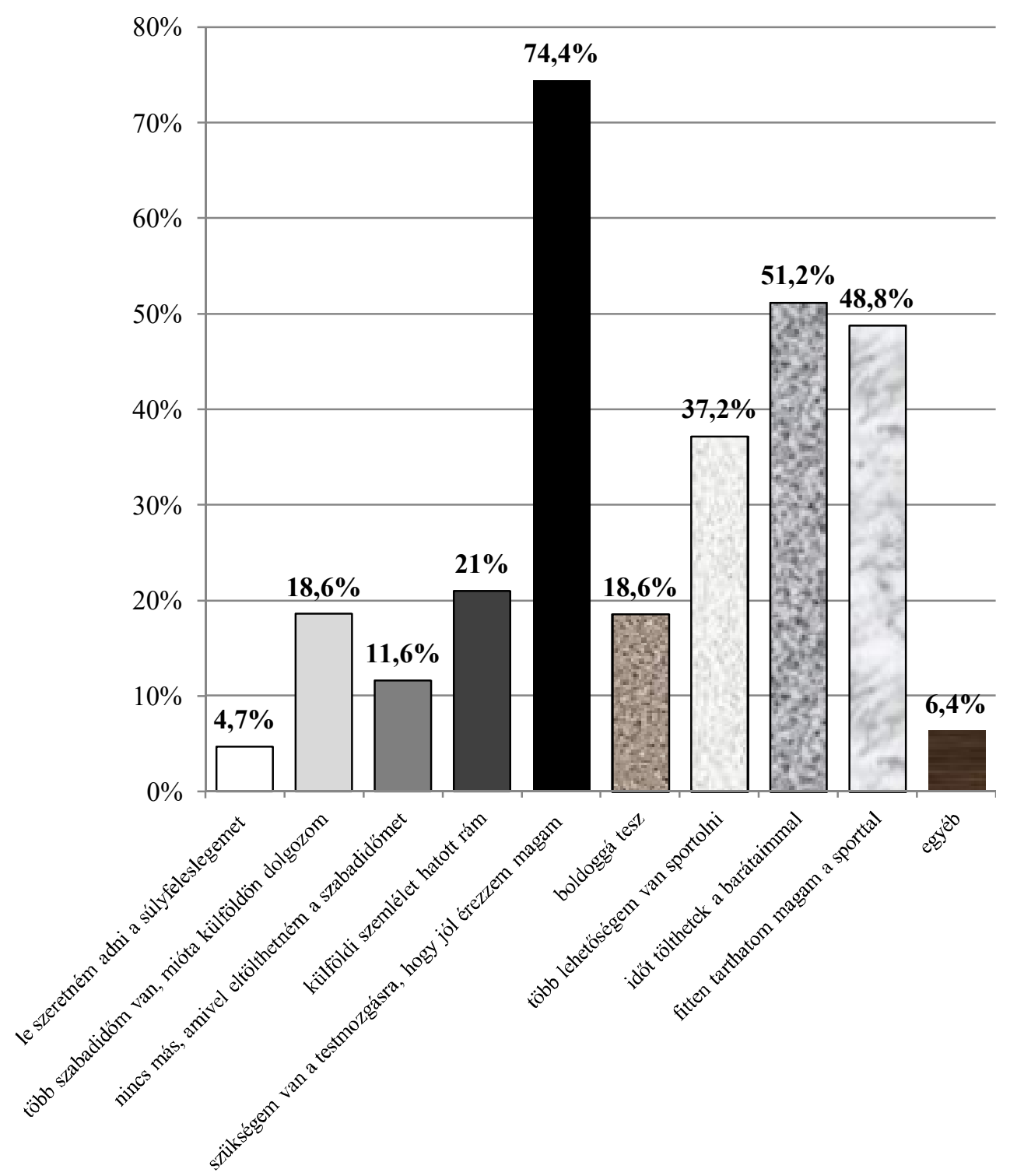

Forrás: Saját szerkesztés

7. ábra. A sportolási motiváció okai

(A válaszadók több választ is megjelölhettek egyidejűleg.)

Arra is kíváncsiak voltunk a fent leírtak tükrében, hogy milyen okot jelölnek meg a nem sportolók a fizikai aktivitás elhanyagolásának okaként.

Sajnálatos módon a nem sportoló válaszadók 69\%-a azt vallotta, hogy sosem volt számára fontos a sport és 30\% érezte úgy, hogy túl fáradt a sporthoz, 23\% pedig azt, hogy az egészségi állapota korlátozza ebben (8. ábra). 


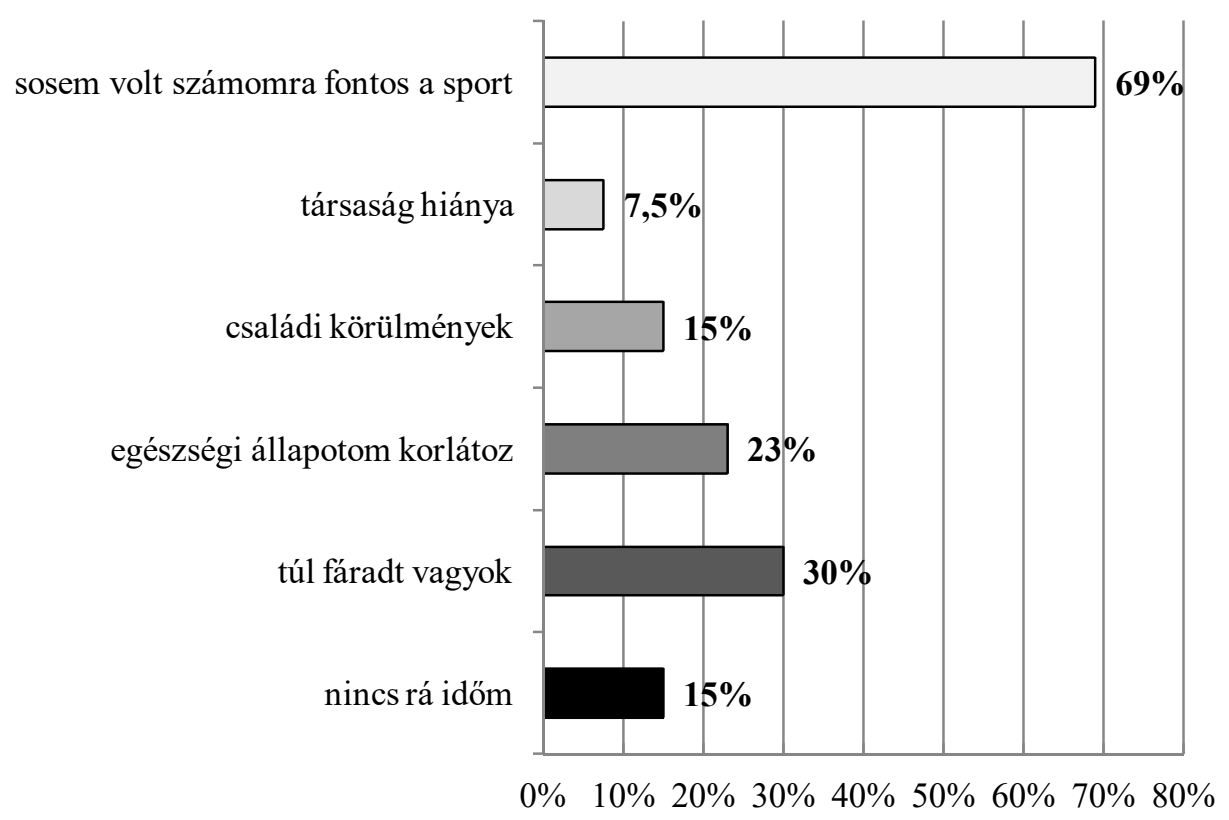

Forrás: Saját szerkesztés

8. ábra. A sportolás hiányának okai

Végezetül arra voltunk kíváncsiak, hogy mutatkozik-e valamilyen különbség a nők és a férfiak között, sportolási szokásaik megváltozásában. Nem találtunk érdemi különbséget a nemek között a sportolás illetve a nem-sportolás indokaiban. Ugyanakkor, bár mind a férfiak, mind a nők körében nőtt a rendszeresen sportolók aránya, ez a változás a nők körében jelentősebbnek bizonyult (nők: 57,1\%-ról 91,7\%-ra, férfiak: 45,2\%-ról 64,5\%-ra).

\section{Összegzés}

A külföldön munkát keresők számára egy új ország számos előnyt jelenthet, ugyanakkor veszélyeket, kockázatokat is magában rejt. A célországban az élet- és munkakörülmények, kulturális szokások jelentősen eltérhetnek a megszokottól, és az egészségügyi ellátáshoz való jog is eltérő lehet, mint az illető hazájában. Mindezek következtében mind a munkavállaló esetében, mind a családtagok, gyermekek vonatkozásában számos egészségügyi kockázat léphet fel.

Megfigyeléseink alapján párhuzamosságot vélünk felfedezni a világ számos részén, korábbi kutatások eredményeiként leírt, a külföldi munkavállalók körében leggyakrabban előforduló megbetegedések, valamint a rendszeres testmozgás által pozitív irányba befolyásolt egészségügyi problémák között.

Kutatásunk során 60 fö, Németországban dolgozó magyar munkavállalót kérdeztünk meg sportolási szokásairól. Megállapítható volt, hogy az irodalmi adatokkal 
ellentétben, a sportolási szokások tekintetében pozitív változás figyelhető meg a külföldre költözés következtében. A rendszeresen sportolók aránya a megkérdezettek körében51,7\%-ról 76,8\%-ra változott. Ehhez hozzájárulhat a célországban Németországban - a munkaadók itthoninál magasabb fokú társadalmi felelősségvállalása, az üzhető sportágak szélesebb választéka (pl. síelés), a jobban kiépített infrastruktúra (pl. túrázás, nordic walking, kerékpározás), valamint az egészségtudatosabb társadalmi környezet is.

Mindezek arra hívják fel a figyelmet, hogy az egészségmagatartás szempontjából rendkívül fontos a társadalmi tudatformálás, az egészséges életmódra nevelés, a lakosság szemléletmódjának célirányos formálása, valamint a rendszeres sportolás feltételei megteremtésének mind szélesebb körben történő biztosítása. Ehhez a politikai döntéshozók, a munkaadók, a civil szervezetek, a helyi közösségek együttes munkája és össztársadalmi intézkedések szükségesek.

\section{Irodalomjegyzék}

1. Abdulbari B (2017): Health status and working condition of migrant workers: Major public health problems. International Journal of Preventive Medicine (8):68. DOI: https://doi.org/10.4103/ijpvm.ijpvm 39616

2. Andersen LB, Schnohr P, Schroll M, Hein HO (2000): All-cause mortality associated with physical activity during leisure time, work, sports and cycling to work. Archives of Internal Medicine (160):1621-1628. DOI: https://doi.org/10.1001/archinte.160.11.1621

3. Blaskó Zsuzsa, Gödri Irén (2016): Magyarországról kivándorlók társadalmi és demográfiai összetétele. In: Blaskó Zsuzsa, Fazekas Károly [szerk.]: Munkaerőpiaci tükör. MTA KRTK KTI, Budapest, 59-67.

4. Blaskó Zsuzsa, Szabó Laura (2015): Gyermeket hátrahagyó migráció Magyarországon. Közelkép 86-88.

5. Bocskor Ákos (2016): Képzettség és munkaerőpiac a válság utáni Európában. Educatio (25):145-148.

6. Bodnár Katalin, Szabó Lajos Tamás (2014): A kivándorlás hatása a hazai munkaerőpiacra. MNB-tanulmányok 114. Budapest

7. Clarke J, Salt J (2003): Work permits and foreign labour in the UK: A statistical review. Labour Market Trends (11): 563-574.

8. Dustmann CH, Frattini T, Rosso A (2015): The effect of emigration from Poland on Polish wages. The Scandinavian Journal of Economics (117): 522564. DOI: https://doi.org/10.1111/sjoe.12102

9. Elsner B (2013): Does emigration benefit the stayers? Evidence from EU enlargement. Journal of Population Economics (26): 531-553.

10. Fazekas Károly, Köllő János (2017): Munkaerőpiaci tükör. 2016. MTA Közgazdaság- és Regionális Tudományi Kutatóközpont Közgazdaságtudományi Intézet, Budapest.

11. Hárs Ágnes, Simon Dávid (2016): Munkaerő-migráció, ingázás, kivándorlás. A magyarok munkavállalási célú emigrációját magyarázó tényezők hatása és vál- 
tozása az uniós csatlakozás óta. In: Blaskó Zsuzsa-Fazekas Károly [szerk.]: Munkaerőpiaci tükör. MTA Közgazdaság- és Regionális Tudományi Kutatóközpont Közgazdaságtudományi Intézet, Budapest, 72-85.

12. Hazans M (2016): Migration experience of the Baltic countries in the context of economic crisis. In: Kahanec M, Zimmermann KF [szerk.]: Labor migration, EU enlargement, and the great recession. Springer. Berlin - Heidelberg, 297344. DOI: https://doi.org/10.1007/978-3-662-45320-9 13

13. Desai I D, Garcia Tavares M L, Dutra de Oliveira B S, Douglas A, Duarte F A M, Dutra de Oliveira J E (1980): Food habits and nutritional status of agricultural migrant workers in Southern Brazil. The American Journal of Clinical Nutrition (33): 702-714. DOI: https://doi.org/10.1093/ajcn/33.3.702

14. Kahanec M, Pytliková M, Zimmermann K F (2016): The free movement of workers in an enlarged European Union: Institutional underpinning of economic adjustment. In: Kahanec M, Zimmermann K F [szerk.]: Labor migration, EU enlargement, and the great recession. Springer. Berlin - Heidelberg, 1-34. DOI: https://doi.org/10.1007/978-3-662-45320-9 1

15. Kállai Barbara, Lengyelné Pogácsás Mária, Nyírcsák János (2016): Munkaerőpiac, külföldi munka és tanulás. Acta Medicinae et Sociologica (7): 48-81. DOI: https://doi.org/10.19055/ams.2016.7/20-21/4

16. Kulinyi Márton (2015): A fiatalok külföldi munkavállalás. Munkaügyi Szemle (3) https://www.munkaugyiszemle.hu/fiatalok-kulfoldi-munkavallalasa (Letöltve: 2019. 05.10.)

17. Matthews CE, Jurj AL, Shu XO, Li HL, Yang G, Li Q, Gao YU, Zheng W (2000): Influence of exercises, walking, cycling and overall non exercise physical activity on mortality in Chinese women. American Journal of Epidemiology (165): 1343-1350. DOI: https://doi.org/10.1093/aje/kwm088

18. Mucci N, Traversini V, Giorgi G, Garzaro G, Fiz-Perez J, Campagna M, Rapisarda V, Tommasi E, Montalti M, Arcangeli G (2019): Migrant workers and physical health: An umbrella review. Sustainability (11): 232-254. DOI: https://doi.org/10.3390/su11010232

19. Tsai SY (2012): A study of the health-related quality of life and work-related stress of white-collar migrant workers. International Journal of Environmental Research and Public Health (9): 3740-3754. DOI: https://doi.org/10.3390/ijerph9103740

20. Szabó Fruzsina (2016): Szétszakított magyar Skype-családok. Megéri? https:/hvg.hu/gazdasag/201646_hatrahagyott_gyerekek_kulfoldi_munka_b untudat skypecsaladok. (Letöltve: 2019.05.10.)

21. Votisky Petra (2015): Gyerekek beilleszkedése külföldön. http://nokkulfoldon.hu/gyerekek-beilleszkedese-kulfoldon/ (Letöltve: 2019. 05.10.)

22. Votisky Petra (2016): Itthon hagyott gyerekek. http://nokkulfoldon.hu/itthonhagyott-gyerekek/

23. Warlburton DER, Nicol CW, Bredin SSD (2016): Health benefits of physical activity: the evidence. Canadian Medical Association Journal (174):801-809. DOI: https://doi.org/10.1503/cmaj.051351 